\title{
DESIGN OF NEW POTENT INSECTICIDES OF ORGANOPHOSPHATE DERIVATIVES BASED ON QSAR ANALYSIS
}

\author{
Mudasir ${ }^{*}$, Yari Mukti Wibowo, and Harno Dwi Pranowo \\ Austrian-Indonesian Centre (AIC) for Computational Chemistry, Department of Chemistry, \\ Faculty of Mathematics and Natural Sciences, Universitas Gadjah Mada, \\ Sekip Utara P.O. Box Bls. 21, Yogyakarta 55281, Indonesia
}

Received November 22, 2012; Accepted February 26, 2013

\begin{abstract}
Design of new potent insecticide compounds of organophosphate derivatives based on QSAR (Quantitative Structure-Activity Relationship) analytical model has been conducted. Organophosphate derivative compounds and their activities were obtained from the literature. Computational modeling of the structure of organophosphate derivative compounds and calculation of their QSAR descriptors have been done by AM1 (Austin Model 1) method. The best QSAR model was selected from the QSAR models that used only electronic descriptors and from those using both electronic and molecular descriptors. The best QSAR model obtained was:

$\log L D_{50}=50.872-66.457 q C 1-65.735 q C 6+83.115 q O 7$

$\left(n=30, r=0.876\right.$, adjusted $r^{2}=0.741, F_{c a} / F_{t a b}=9.636$, PRESS $\left.=2.414 \times 10^{-6}\right)$

The best QSAR model was then used to design in silico new compounds of insecticide of organophosphate derivatives with better activity as compared to the existing synthesized organophosphate derivatives. So far, the most potent insecticide of organophosphate compound that has been successfully synthesized had log $L D_{50}$ of 5.20, while the new designed compound based on the best QSAR model, i.e.: 4-(diethoxy phosphoryloxy) benzene sulfonic acid, had log $L D_{50}$ prediction of -7.29. Therefore, the new designed insecticide compound is suggested to be synthesized and tested for its activity in laboratory for further verification.
\end{abstract}

Keywords: QSAR analysis; insecticides; organophosphate; semi-emphiric AM-1; molecular design

\section{ABSTRAK}

Telah dilakukan desain senyawa insektisida baru turunan organofosfat berdasarkan pada model analisis Hubungan Kuantitatif Struktur-Aktivitas (HKSA). Senyawa turunan organofosfat dan aktivitasnya diperoleh dari literatur. Pemodelan komputasi terhadap struktur senyawa turunan organofosfat dan perhitungan deskriptor HKSAnya telah dilakukan menggunakan metode AM1 (Austin Model 1). Model HKSA terbaik dipilih dari model HKSA yang hanya menggunakan deskriptor elektronik dan dari model yang menggunakan baik deskriptor elektronik maupun molekul. Model HKSA terbaik yang diperoleh adalah:

$\log L D_{50}=50,872-66,457 q C 1-65,735 q C 6+83,115 q O 7$

$\left(n=30, r=0,876\right.$, adjusted $r^{2}=0,741, F_{c a l} / F_{t a b}=9,636$, PRESS $\left.=2,414 \times 10^{-6}\right)$

Model HKSA terbaik tersebut kemudian digunakan untuk merancang secara in silico senyawa insektisida baru turunan organofosfat yang mempunyai aktivitas lebih baik dibandingkan dengan turunan organofosfat yang sudah ada. Sejauh ini, insektisida organofosfat paling ampuh yang telah berhasil disintesis mempunyai log $L D_{50}$ sebesar 5,20, sedangkan senyawa baru yang telah dirancang berdasarkan model HKSA terbaik, yakni: asam 4-(diethoxy phosphoryloxy) benzena sulfonat mempunyai log $L D_{50}$ prediksi sebesar $-7,29$. Oleh karena itu, senyawa insektisida baru yang telah dirancang ini disarankan untuk disintesis dan diuji aktivitasnya di laboratorium untuk verifikasi lebih lanjut.

Kata Kunci: analisis HKSA; insektisida, organofosfat; semi-empirik AM-1; perancangan molekul

\section{INTRODUCTION}

Insecticides are chemical or biological origin agents that control insects. The control is resulted from killing the insect or otherwise preventing it from engaging in behaviors deemed destructive. Insecticides of organophosphates (OPs) classes produces their neurotoxic effects by inhibiting acetylcholinesterase (AchE), a critical enzyme involved in nerve impulse transmission [1]. Chronic toxicity caused by OP exposure

* Corresponding author. Tel/Fax : +62-274-545188/513339

Email address : mudasir@ugm.ac.id

Mudasir et al. 


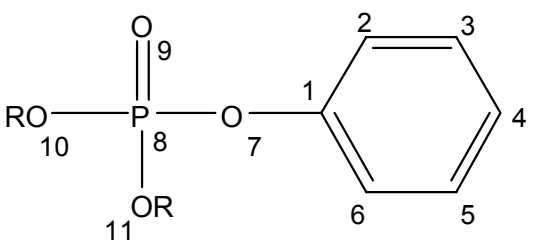

Fig 1. Chemical structure of organophosphate insecticides. Variation of substituent was done at $\mathrm{C} 3$ or C4 as well as R. Atomic numbering is used only for the purpose of molecular model

ranges from cholinesterase inhibition in plasma, erythrocytes and brain tissue to the appearance of clinical signs of long-term damage to the central nervous system as well as the peripheral nervous system [2-3].

The cholinesterase inhibition by organophosphate poisoning generally is not reversible, meaning that the insecticide does not release the bound cholinesterase [4]. In some cases, AChE that is inhibited by certain types of organophosphorus esters is irreversibly phosphorylated and spontaneous regeneration does not occur [5]. As a result, decrease in sensitivity of AchE to inhibit insecticides has been resulted in insecticide resistance for many insects. Molecular studies indicated that the decrease in inhibition sensitivity of AchE is due to mutation(s) of the AchE gene. These mutations cause structural modifications of the enzyme, which often result in modification of enzyme property, including its sensitivity to inhibition by insecticides.

Since 1970s, the use of most persistent organochlorine insecticides has been restricted, consequently the less persistent but highly effective organophosphate agents has been the most widespread pesticides used worldwide and become the insecticides of first choice. Currently, all efforts are focused on developing insecticides with new, and safer modes of action. A rational approach for developing new insecticides is to make use of QSAR (Quantitative Structure-Activity Relationship) models for the rapid prediction and virtual pre-screening of insecticide activity.

A QSAR equation is a mathematical equation that correlates the biological activity to a wide variety of physical or chemical parameters. There are many examples available in the literature in which QSAR models have been used successfully for the screening of compounds for biological activity [6-9]. The pre-requisite of developing QSAR equations is the availability of a wide range of molecular structures and their complementary activities. QSAR studies have been successfully done for the organophosphates and carbamates [10] using only free-energy-related physiochemical substituent parameters such as $\pi, \sigma$ and others. Furthermore, Naik, et al. [11] has conducted QSAR study for the organophosphates and carbamates using E-state, electronic, structural, topological, quantum mechanics and physicochemical based descriptors, which can be calculated without structural alignments. The behavior of QSAR models was examined with a variety of statistical parameters in line with what has been used by Deswal and Roy [12] for the development of thrombin inhibitors.

Based on the data of acute toxicity $\left(\mathrm{LD}_{50}, \mathrm{~mol} \mathrm{~L}^{-1}\right)$ of OP derivatives reported by Hansch et al. [13] and Gandhe and Purnanand [14] for the compound of 24 (see Table 1), we here report a QSAR study on organophosphate derivatives (Fig. 1) based on semiempirical AM1 calculation of quantum-chemical descriptors. The best QSAR model obtained from the study was then used to design in silico new compounds of insecticide of organophosphate derivatives with better activity as compared to the existing synthesized organophosphate derivatives.

\section{EXPERIMENTAL SECTION}

\section{Data Set}

A total of 35 insecticide analogues were used in the study and were taken from various sources as mentioned in Table 1. Structural modifications are mainly introduced at varying radicals at positions $X$ and $\mathrm{R}$ in the scaffold structure. The acute toxicity data $\left(\mathrm{LD}_{50}, \mathrm{~mol} \mathrm{~L}^{-1}\right)$ of these compounds to housefly (Musca nebulo L.) were taken from Hansch et al. [13], except for the compound 24 from Gandhe and Purnanand [14]. All chemicals are analogues to methyl and ethyl paraoxons (compounds 12 and 22), which are capable of inhibiting AChE directly [14]. The selected chemicals have significant differences in structure for the substituents $\mathrm{X}$ at meta and para positions ranging from electron-donating group $\left(-\mathrm{CH}_{3}\right)$ to electron-withdrawing group $\left(-\mathrm{NO}_{2}\right)$, while the alkyl group $\mathrm{R}$ varies from methyl to butyl.

\section{Computational Validation and Descriptor Calculation}

In order to obtain the most suitable method of calculation, the parent compound of organophosphate was first computationally modeled using either Austin Model (AM) 1 or Parameterized model (PM3) available in Hyperchem 7.0 software program to calculate chemical shift of the compound using ${ }^{1} \mathrm{H}$ HyperNMR package. The calculated chemical shift data of the compound was then compared to the ones available from experimental H-NMR measurement [15]. The method of calculation (AM1 or PM3) giving smallest differences between calculated and experimental data was chosen as the most suitable method and was used 
Table 1. Chemical structure and insecticide activity of organophosphate derivatives against housefly (Musca nebulo L.) $[11]$

\begin{tabular}{|c|c|c|c|c|}
\hline No. & Compounds & $\mathrm{R}$ & $\mathrm{X}$ & $\log \operatorname{LD}_{50}$ \\
\hline 1 & Dimethyl phenyl phosphate & $\mathrm{CH}_{3}$ & $\mathrm{H}$ & -2.75 \\
\hline 2 & Dimethyl m-tolyl phosphate & $\mathrm{CH}_{3}$ & $3-\mathrm{CH}_{3}$ & -2.00 \\
\hline 3 & Dimethyl p-tolyl phosphate & $\mathrm{CH}_{3}$ & $4-\mathrm{CH}_{3}$ & -1.99 \\
\hline 4 & 4-methoxy phenyl dimethyl phosphate & $\mathrm{CH}_{3}$ & $4-\mathrm{OCH}_{3}$ & -2.00 \\
\hline 5 & 3-chlorophenyl dimethyl phosphate & $\mathrm{CH}_{3}$ & $3-\mathrm{Cl}$ & -2.10 \\
\hline 6 & 4-chlorophenyl dimethyl phosphate & $\mathrm{CH}_{3}$ & $4-\mathrm{Cl}$ & -2.60 \\
\hline 7 & 3-bromophenyl dimethyl phosphate & $\mathrm{CH}_{3}$ & $3-\mathrm{Br}$ & -4.00 \\
\hline 8 & 4-bromophenyl dimethyl phosphate & $\mathrm{CH}_{3}$ & $4-\mathrm{Br}$ & -3.53 \\
\hline 9 & 3-cianophenyl dimethyl phosphate & $\mathrm{CH}_{3}$ & $3-\mathrm{CN}$ & -4.99 \\
\hline 10 & 4-cianofenil dimethyl phosphate & $\mathrm{CH}_{3}$ & $4-\mathrm{CN}$ & -4.84 \\
\hline 11 & Dimethyl 3-nitrophenyl phosphate & $\mathrm{CH}_{3}$ & $3-\mathrm{NO}_{2}$ & -4.90 \\
\hline 12 & Dimethyl 4-nitrophenyl phosphate & $\mathrm{CH}_{3}$ & $4-\mathrm{NO}_{2}$ & -5.10 \\
\hline 13 & Diethyl phenyl phosphate & $\mathrm{C}_{2} \mathrm{H}_{5}$ & $\mathrm{H}$ & -3.20 \\
\hline 14 & Diethyl p-tolyl phosphate & $\mathrm{C}_{2} \mathrm{H}_{5}$ & $4-\mathrm{CH}_{3}$ & -3.00 \\
\hline 15 & 3-chlorophenyl diethyl phosphate & $\mathrm{C}_{2} \mathrm{H}_{5}$ & $3-\mathrm{Cl}$ & -3.80 \\
\hline 16 & 4-chlorophenyl diethyl phosphate & $\mathrm{C}_{2} \mathrm{H}_{5}$ & $4-\mathrm{Cl}$ & -3.72 \\
\hline 17 & 3-bromophenyl diethyl phosphate & $\mathrm{C}_{2} \mathrm{H}_{5}$ & $3-\mathrm{Br}$ & -4.11 \\
\hline 18 & 4-bromophenyl diethyl phosphate & $\mathrm{C}_{2} \mathrm{H}_{5}$ & $4-\mathrm{Br}$ & -4.06 \\
\hline 19 & 3-cianophenyl diethyl phosphate & $\mathrm{C}_{2} \mathrm{H}_{5}$ & $3-\mathrm{CN}$ & -5.00 \\
\hline 20 & 4-cianophenyl diethyl phosphate & $\mathrm{C}_{2} \mathrm{H}_{5}$ & $4-\mathrm{CN}$ & -5.10 \\
\hline 21 & Diethyl 3-nitrophenyl phosphate & $\mathrm{C}_{2} \mathrm{H}_{5}$ & $3-\mathrm{NO}_{2}$ & -5.10 \\
\hline 22 & Diethyl 4-nitrophenyl phosphate & $\mathrm{C}_{2} \mathrm{H}_{5}$ & $4-\mathrm{NO}_{2}$ & -5.20 \\
\hline 23 & 2,4-dichlorophenyl diethyl phosphate & $\mathrm{C}_{2} \mathrm{H}_{5}$ & $2,4-\mathrm{Cl}$ & -4.30 \\
\hline 24 & 2,5-dichlorophenyl diethyl phosphate & $\mathrm{C}_{2} \mathrm{H}_{5}$ & $2,5-\mathrm{Cl}$ & -4.10 \\
\hline 25 & Dibuthyl phenyl phosphate & $\mathrm{C}_{4} \mathrm{H}_{9}$ & $\mathrm{H}$ & -2.50 \\
\hline 26 & Dibuthyl m-tolyl phosphate & $\mathrm{C}_{4} \mathrm{H}_{9}$ & $3-\mathrm{CH}_{3}$ & -2.00 \\
\hline 27 & Dibuthyl p-tolyl phosphate & $\mathrm{C}_{4} \mathrm{H}_{9}$ & $4-\mathrm{CH}_{3}$ & -2.10 \\
\hline 28 & Dibuthyl 4-methoxyiphenyl phosphate & $\mathrm{C}_{4} \mathrm{H}_{9}$ & $4-\mathrm{OCH}_{3}$ & -2.10 \\
\hline 29 & Dibuthyl 3-chlorophenyl phosphate & $\mathrm{C}_{4} \mathrm{H}_{9}$ & $3-\mathrm{Cl}$ & -2.80 \\
\hline 30 & Dibuthyl 4-chlorophenyl phosphate & $\mathrm{C}_{4} \mathrm{H}_{9}$ & $4-\mathrm{Cl}$ & -2.50 \\
\hline 31 & 4-bromophenyl dibuthyl phosphate & $\mathrm{C}_{4} \mathrm{H}_{9}$ & $4-\mathrm{Br}$ & -2.95 \\
\hline 32 & Dibuthyl 3-cianophenyl phosphate & $\mathrm{C}_{4} \mathrm{H}_{9}$ & $3-\mathrm{CN}$ & -4.00 \\
\hline 33 & Dibuthyl 4-cianophenyl phosphate & $\mathrm{C}_{4} \mathrm{H}_{9}$ & $4-\mathrm{CN}$ & -4.01 \\
\hline 34 & Dibuthyl 3-cianophenyl phosphate & $\mathrm{C}_{4} \mathrm{H}_{9}$ & $3-\mathrm{NO}_{2}$ & -4.21 \\
\hline 35 & Dibuthyl 4-nitrophenyl phosphate & $\mathrm{C}_{4} \mathrm{H}_{9}$ & $4-\mathrm{NO}_{2}$ & -4.38 \\
\hline
\end{tabular}

for further calculation in this study.

Based on the result of method validation, the descriptors of QSAR analysis that used for multiple linear regression analysis consisting of atomic netcharge $(q)$, dipole moment $(\mu)$ were calculated by semiempirical AM-1 MO SCF method using HyperChem Version 7.0. Surface area (SA) and partition coefficient $(\log P)$ descriptors were obtained from QSAR properties available in the package program. Before calculation of predictors was done, the geometries of the insecticide molecules were optimized on the basis of conjugate gradient method using Polak-Ribiere algorithm with convergence limit of $0.001 \mathrm{kcal} \mathrm{mol}^{-1} \mathrm{~A}^{-1}$.

\section{Generation of QSAR Model Using Regression Analysis}

The correlation models between descriptors and insecticide activity were evaluated by multiple linear regression analysis using software SPSS 13 for Windows $^{\mathrm{TM}}$ Backward method was used for all regression analysis on the basis of the two following general linear equations:

$\log \mathrm{LD}_{50}=\sum P_{(q i)} q_{(i)}+P_{(\mu)} \mu+D$

$\log \mathrm{LD}_{50}=\sum P_{(q i)} q_{(i)}+P_{(\mu)} \mu+P_{(S A)} S A+P_{(\log P)} \log P+D$

The equation (1) is the general QSAR model involving electronic descriptors only, while equation (2) represents the general QSAR equation model using combination of electronic and molecular parameters. The symbol $P$ in the equations stands for a fitting coefficient of corresponding descriptors and $D$ is a constant.

\section{Design of New Compounds}

The best QSAR model obtained previously was used as guidance in designing new, safer and presumably more potent insecticides. In designing the 
new molecules, we refer to the synthesized molecules with highest activity that has been reported, i.e. the ones with $\mathrm{R}=-\mathrm{C}_{2} \mathrm{H}_{5}$ and $X$ substituents were varied so that it consisted of electron withdrawing or donating groups. To evaluate the effect of $X$ substituents on insecticide activity, the $R$ groups were kept constant using ethyl group (compound 36-450 while X was varied. Similarly, to examine the influence of $R$ on the activity, the $X$ substituents were kept constant (compounds 46-49) while the length of $R$ was varied from one to four $C$ atoms. Detailed new designed organophosphate derivatives are given in Table 2.

\section{RESULT AND DISCUSSION}

\section{Computational Validation}

In searching the most suitable calculation method for modeling series of insecticide derivatives, two semiempirical methods AM1 and PM3 has been tested for the calculation of chemical shift $(\delta)$ dimethyl phenyl phosphate (Fig. 2) using HyperNMR available in the Hyperchem 7.0 program with the torsion angle of C1-07-P8-09 kept at $180^{\circ}$. The results of the calculation were then compared to those obtained from experimental measurements $\left({ }^{1} \mathrm{H}-\mathrm{NMR}, 400 \mathrm{MHz}\right)$ [15] as listed in Table 2.

Table 2 shows clearly that chemical shift data obtained from ${ }^{1} \mathrm{H}$ HyperNMR calculation using AM1 have

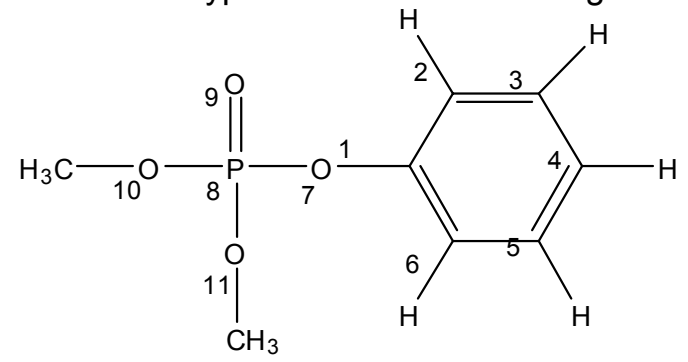

Fig 2. Chemical structure of dimethyl phenyl phosphate and its atomic numbers

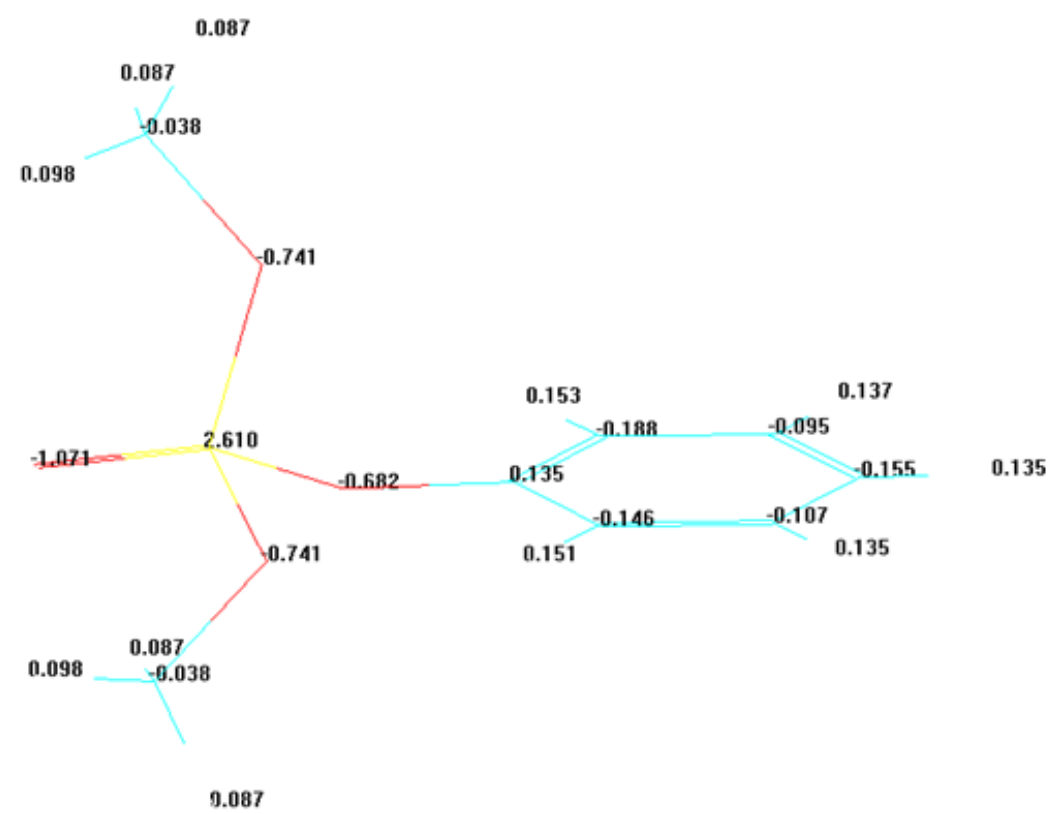

Fig 3. 3D-structure of dimethyl phenyl phosphate and its atomic net-charges after geometrical optimization using AM1 method

Table 2. Comparison of calculated and experimental NMR chemical shift data $(\delta, \mathrm{ppm})$ for hydrogen atoms in phenyl ring (upper) and in two methyl groups (lower) of dimethyl phenyl phosphate

\begin{tabular}{|c|c|c|c|c|c|c|}
\hline Methods & $\mathrm{H} 12$ & $\mathrm{H} 13$ & \multicolumn{2}{|c|}{$\mathrm{H} 14$} & $\mathrm{H} 15$ & $\mathrm{H} 16$ \\
\hline Calculated AM1 & 6.388 & 7.187 & \multicolumn{2}{|c|}{6.983} & 7.316 & 7.731 \\
\hline Calculated PM3 & 6.336 & 7.204 & \multicolumn{2}{|c|}{6.951} & 7.143 & 6.712 \\
\hline Experimental [15] & 7.31 & 7.18 & \multicolumn{2}{|c|}{7.14} & 7.18 & 7.31 \\
\hline Methods & $\mathrm{H} 19$ & $\mathrm{H} 2 \mathrm{O}$ & $\mathrm{H} 21$ & $\mathrm{H} 22$ & $\mathrm{H} 23$ & $\mathrm{H} 24$ \\
\hline Calculated AM1 & 3.551 & 3.197 & 2.955 & 3.554 & 2.951 & 3.193 \\
\hline Calculated PM3 & 2.853 & 1.164 & 3.182 & 2.846 & 3.171 & 1.158 \\
\hline Experimental [15] & 3.83 & 3.83 & 3.83 & 3.83 & 3.83 & 3.83 \\
\hline
\end{tabular}


Table 3. Statistical parameters of 5 selected QSAR models of organophosphate derivatives

\begin{tabular}{|c|c|c|c|c|c|c|c|}
\hline Model & Descriptors & $r$ & $r^{2}$ & Adjusted $\mathrm{r}^{2}$ & SD & $\mathrm{F}_{\text {cald }} / \mathrm{F}_{\text {tab }}$ & PRESS \\
\hline 1 & $\begin{array}{c}q C 1, q C 2, q C 4, q C 5, q C 6 \\
q 07, q P 8, q 09, q 011\end{array}$ & 0.936 & 0.876 & 0.820 & 0.474 & 6.539 & $2.600 \times 10^{-7}$ \\
\hline 2 & $\mathrm{qC} 1, \mathrm{qC} 2, \mathrm{qC} 4, \mathrm{qC} 6, \mathrm{qO} 7, \mathrm{qO} 9$ & 0.932 & 0.869 & 0.834 & 0.455 & 10.028 & $4.404 \times 10^{-4}$ \\
\hline 3 & $\mathrm{qC} 1, \mathrm{qC} 2, \mathrm{qC} 4, \mathrm{qC} 6, \mathrm{qO} 7$ & 0.918 & 0.843 & 0.810 & 0.486 & 9.847 & $1.583 \times 10^{-6}$ \\
\hline 4 & qC1, qC2, qC6, qO7 & 0.905 & 0.820 & 0.791 & 0.511 & 10.299 & $4.057 \times 10^{-4}$ \\
\hline 5 & qC1, qC6, qO7 & 0.876 & 0.768 & 0.741 & 0.568 & 9.636 & $2.414 \times 10^{-6}$ \\
\hline
\end{tabular}

a better agreement with those resulted from experimental measurement as compared to those calculated by PM3 method, suggesting that AM1 method describe the chemical conformation of organophosphate derivatives more accurately than does PM3 methods. Therefore, AM1 method has been selected as calculation method for further modeling of insecticide compounds in this study using C1-07-P8-O9 torsion angle of $180^{\circ}$ because this angle give the lowest potential energy.

\section{Geometrical Optimization of Insecticide Structure}

The optimized structure of insecticide conformation is illustrated in Fig. 3. It is clearly seen from Fig. 3 that oxygen atom has negative charge due to its higher electronegativity than other atoms in the molecule so that electron cloud nearby is attracted closer to the oxygen atom. Accordingly, carbon atom (C1) in the phenyl group which is close to oxygen $(\mathrm{O} 7)$ is positively charged because its electron is slightly withdrawn towards the oxygen atom due to the high electronegativity of 07 . On the other hand, C2, C3, C4, C5 and C6 atoms due to their position which are quite far away from $\mathrm{O} 7$ atom are not affected, therefore all of these atoms have a slight negative charge.

Moreover, in the phosphate groups, $\mathrm{P}$ atom is surrounded by four $\mathrm{O}$ atoms, resulting in relatively low electron density of $\mathrm{P}$. As a result, this atom possesses large negative charge and therefore binds strongly with $O$ atom of serine of acetylcholine esterase enzyme when this insecticide is interacted with the enzyme in neural system. This strong binding causes phosphate group difficult to unbind from $\mathrm{O}$-serine in the enzyme, resulting in deactivation of the enzyme.

\section{Generation and Selection of QSAR Model}

In searching for best models according to Eq. (1) and (2), the relative importance of descriptors, i.e.: atomic net-charge and other properties can be recognized from the variable coefficient size $(P)$ and from the result of inter variable correlation analysis by bivariate method. This allows the exclusion of less relevant descriptor and gradual evaluation of the structure of the active center of the insecticides.
To obtain the best model that correlates independence variables (descriptors) and dependence variable (biological activity), multiple linear regression analysis using SPSS version 13 for Windows has been performed. The 35 active compounds with their acute toxicity to housefly were randomly divided into a training set of 30 compounds and a test set of 5 compounds. Fifteen (15) independent variables consisting of 11 atomic net-charges (q) of C1, C2, C3, C4, C5, C6, 07, P8, 09, O10 and O11 as well as other properties such as dipole moment $(\mu)$, surface area (SA) and partition coefficient (Log P) were included in the model set-up. At the first step, all variables are included in the model and the less relevant variables were then eliminated gradually from the model by enter and backward method. This procedure finally gives 5 QSAR models as listed in Table 3. From Table 3, it is immediately emerged that all selected models show a good correlation $(r \approx 0.9)$ between biological activity and descriptors selected for fitting. This suggests that justification of the best model among 5 models selected in Table 3 is not adequate only by comparing the $r$ size, because its value is almost similar. Therefore, other statistical parameters such as $F_{\text {calc }} / F_{\text {tab }}$ (model significance), SD (standard deviation) and PRESS (predictive residual sum of square) values should be taken into account. Comparing the above mentioned parameters of the five models, it is also not easy to conclude which one is the best model because their value is not significantly different. However from the view point of simplicity, it is concluded that model 5 is selected as the best QSAR model because this model contains only 3 variables but still give relatively similar statistical parameter values, especially PRESS value. This model could therefore be utilized for rational search and design of new organophosphate insecticides, which is necessary due to the rapid resistance development of many insects, especially in tropical countries. The complete equation of the best model is presented in Equation (3).

$\log \mathrm{LD}_{50}=50.872-66.457 \mathrm{qC} 1-65.735 \mathrm{qC} 6+83.115 \mathrm{qO} 7$

$\mathrm{n}=30, \mathrm{r}=0.876$, adjusted $\mathrm{r}^{2}=0.741, \mathrm{SD}=0.568, \mathrm{~F}_{\text {calc }} / \mathrm{F}_{\text {tab }}=9.636$, PRESS $=2.414 \times 10^{-6}$

\section{Model validation}

It has been selected that model 5 is the best mode I from the point of view of the simplicity of the 
Table 4. Comparison between predicted and experimental values of insecticide activity calculated by selected model for 5 compounds of test set.

\begin{tabular}{ccccccc}
\hline Compounds of & Experimental & \multicolumn{5}{c}{ Predicted Log LD } \\
test set & Log LD $_{50}$ & Model 1 & Model 2 & Model 3 & Model 4 & Model 5 \\
\hline Compound 3 & -1.99 & -2.746 & -2.740 & -2.562 & -2.420 & -2.212 \\
Compound 4 & -2.00 & -2.266 & -2.270 & -2.003 & -1.614 & -1.800 \\
Compound 16 & -3.72 & -3.903 & -3.881 & -3.693 & -3.602 & -3.732 \\
Compound 32 & -4.00 & -3.523 & -3.653 & -3.875 & -3.942 & -3.772 \\
Compound 34 & -4.21 & -4.268 & -4.665 & -4.784 & -4.837 & -4.648 \\
\hline
\end{tabular}

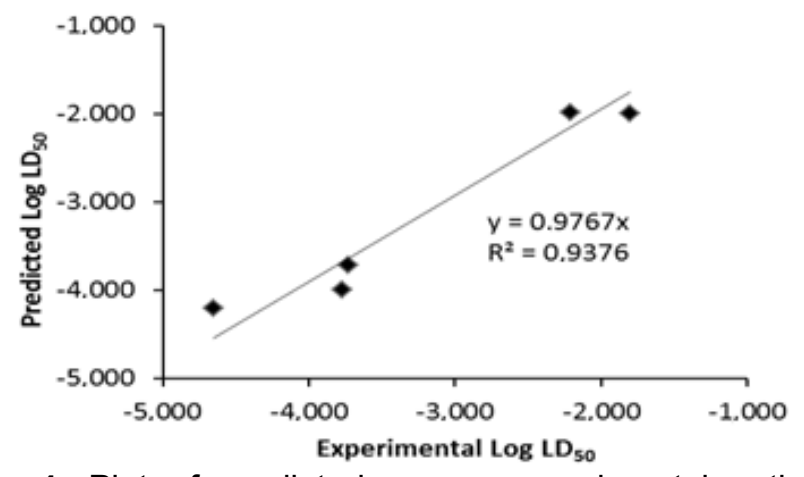

Fig 4. Plot of predicted versus experimental activity values for 5 compounds of test set of organophosphate insecticides calculated by model 5

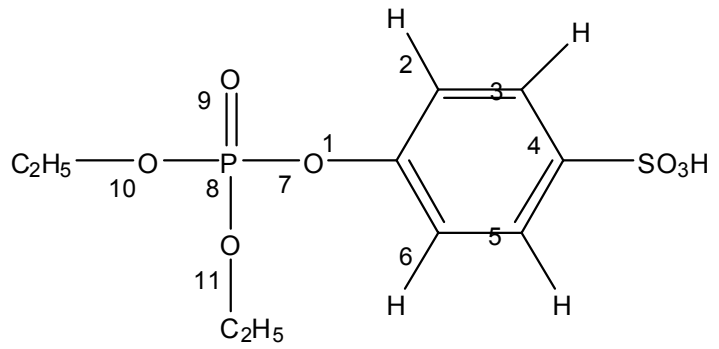

Fig 5. Chemical structure of 4-(diethoxy phosphoriloxy) benzenesulfonic acid

models. To see how good this model predict the activity of the insecticide series, the calculation of the activity for 5 compounds of test set has been performed (Table 4) using model 5 and the result of the calculation (predicted $\left.\log L D_{50}\right)$ is plotted by linear regression method against those obtained by experiments (observed log $L D_{50}$ ) to see how well these two values correlate each other (Fig. 4 , only model 5 is shown). It is observed from this figure that model 5 predicts very well the activity of 5 compounds of test set as can be seen from the values of the slope and correlation coefficient $(r)$ of the plot which is close to unity, i.e.: 1.050 and 0.945 , respectively.

Further validation of the model can also be accessed by comparing the Y-intercept of the graphs. From the five model tested for the calculation of test set compounds, model 5 gives the lowest y-intercept value $(+0.110)$ while the other model ranges from -1.111 to +0.214 , meaning that model 5 only slightly overestimates the true (experimental) value while other models unfortunately either over- or under-estimate severely. The result of validation against 5 compounds of test set demonstrates clearly that model 5 is the most reliable model to be used as guidance in designing the new insecticides of the class.

\section{Design of New Insecticides}

In designing new insecticide molecules of organophosphate derivatives, the best QSAR model obtained is used as a guidance to predict their activity. The selection of $\mathrm{R}$ substituents for the new molecules is based on the previously synthesized molecules having high insecticide activity, i.e. $R=\mathrm{C}_{2} \mathrm{H}_{5}$, while $X$ substituents are varied so that the molecules bear either withdrawing or donating substituents. Detailed new insecticides that have been designed are listed in Table 5 together with their predicted activities calculated using the best QSAR model.

Based on LFER (Linear Free Energy Relationship), in designing new molecules, $X$ substituents are attached to the phenyl ring at paraand meta- positions to give significant contribution of resonance effect. On the other hand, substitution at ortho position is normally difficult to be synthesized due to the steric effect; hence $X$ substituent at this position is not considered in this study.

It is observed from Table 5 that some new designed compounds have predicted activity of $L_{50}$ lower than synthesized insecticides which has been reported in many literatures. The smallest reported value of $L D_{50}$ for synthesized organophosphate insecticides is -5.20 , using $R=\mathrm{C}_{2} \mathrm{H}_{5}$ and $\mathrm{X}=4-\mathrm{NO}_{2}$ as substituents. As can be seen from Table 5 , compound $46,47,48$ and 49 where $X=4-\mathrm{SO}_{3} \mathrm{H}$, an electron withdrawing group, have predicted $\mathrm{LD}_{50}$ lower than those has been reported. Form the lowest predicted $L D_{50}$ value it has been found that compound with $R=$ $\mathrm{C}_{2} \mathrm{H}_{5}$ and $\mathrm{X}=4-\mathrm{SO}_{3} \mathrm{H}$ at position para gives the best activity, while those using longer chain of $\mathrm{R}$ tend to decrease. Therefore, it is concluded that in designing the new compound it is better to use $X$ of withdrawing electron and $\mathrm{R}=\mathrm{C}_{2} \mathrm{H}_{5}$. According to Hassall [16] the stability of the binding of phosphate to O-serine of the enzyme is influenced by the type of $R$ and it has been reported that the organophosphate with $\mathrm{R}=\mathrm{C}_{2} \mathrm{H}_{5}$ has 
Table 5. New designed organophosphate insecticide molecules and its predicted log $L D_{50}$ calculated using the best QSAR model

\begin{tabular}{llrrr}
\hline No. & Compounds & $\mathrm{R}$ & $\mathrm{X}$ & $\begin{array}{r}\text { Predicted } \\
\text { Log } \mathrm{LD}_{50}\end{array}$ \\
\hline 36 & Diethyl 4-ethylphenyl phosphate & $\mathrm{C}_{2} \mathrm{H}_{5}$ & $4-\mathrm{CH}_{2} \mathrm{CH}_{3}$ & -1.957 \\
37 & Diethyl 4-methoxyphenyl phosphate & $\mathrm{C}_{2} \mathrm{H}_{5}$ & $4-\mathrm{OCH}_{3}$ & -2.562 \\
38 & 4-Ethoxyphenyl diethyl phosphate & $\mathrm{C}_{2} \mathrm{H}_{5}$ & $4-\mathrm{OCH}_{2} \mathrm{CH}_{3}$ & -2.461 \\
39 & 4-Aminophenyl diethyl phosphate & $\mathrm{C}_{2} \mathrm{H}_{5}$ & $4-\mathrm{NH}_{2}$ & -0.945 \\
40 & Diethyl 4-(methylamino)phenyl phosphate & $\mathrm{C}_{2} \mathrm{H}_{5}$ & $4-\mathrm{NHCH}_{3}$ & -0.865 \\
41 & 4-(Methylamino)phenyl diethyl phosphate & $\mathrm{C}_{2} \mathrm{H}_{5}$ & $4-\mathrm{N}\left(\mathrm{CH}_{3}\right)_{2}$ & -1.704 \\
42 & Diethyl 4-(methylthio)phenyl phosphate & $\mathrm{C}_{2} \mathrm{H}_{5}$ & $4-\mathrm{SCH}_{3}$ & -3.317 \\
43 & Diethyl 4-(ethylthio) phenyl phosphate & $\mathrm{C}_{2} \mathrm{H}_{5}$ & $4-\mathrm{SCH}_{2} \mathrm{CH}_{3}$ & -3.258 \\
44 & Diethyl 4-formylphenyl phosphate & $\mathrm{C}_{2} \mathrm{H}_{5}$ & $4-\mathrm{CHO}_{2}$ & -4.649 \\
45 & 3-(Diethoxy phosphoriloxy)benzene sulfonic acid & $\mathrm{C}_{2} \mathrm{H}_{5}$ & $3-\mathrm{SO}_{3} \mathrm{H}$ & -4.659 \\
46 & 4-(Diethoxy phosphoriloxy)benzene sulfonic acid & $\mathrm{C}_{2} \mathrm{H}_{5}$ & $4-\mathrm{SO}_{3} \mathrm{H}$ & -7.293 \\
47 & 4-(Dimethoxy phosphoriloxy)benzene sulfonic acid & $\mathrm{CH}_{3}$ & $4-\mathrm{SO}_{3} \mathrm{H}$ & -6.598 \\
48 & 4-(Dipropoxy phosphoriloxy)benzene sulfonic acid & $\mathrm{C}_{3} \mathrm{H}_{7}$ & $4-\mathrm{SO}_{3} \mathrm{H}$ & -7.119 \\
49 & 4-(Dibuthoxy phosphoriloxy)benzene sulfonic acid & $\mathrm{C}_{4} \mathrm{H}_{9}$ & $4-\mathrm{SO}_{3} \mathrm{H}$ & -7.070 \\
\hline
\end{tabular}

strongest interaction with O-serine of the enzyme, hence this compound gives the highest toxicity among the others. Among new designed organophosphate molecules, 4-(diethoxy phosphoriloxy) benzenesulfonic acid is the most potent insecticides $\left(R=\mathrm{C}_{2} \mathrm{H}_{5}, X=4-\right.$ $\mathrm{SO}_{3} \mathrm{H}$, predicted log $\left.\mathrm{LD}_{50}=-7.293\right)$. The chemical structure of this compound is given in Fig. 5 .

From the viewpoint of substituents attached to phenyl groups, it is observed that the most active synthesized organophosphate derivatives have $\mathrm{X}$ substituent $=4-\mathrm{NO}_{2}$ (electron donating group). Similarly, the new designed organophosphate derivatives with the lowest log $L_{50}$ value also possesses electron donating group, i.e. $X=4-\mathrm{SO}_{3} \mathrm{H}$. In this study, the position of $\mathrm{SO}_{3} \mathrm{H}$ has been varied either in the meta- or paraposition to evaluate the effect of electron resonance by comparing the predicted log $L_{50}$ values of the corresponding compounds. Results of the study show that there is a significant difference in the value of predicted log $\mathrm{LD}_{50}$ between para $\left(\mathrm{X}=4-\mathrm{SO}_{3} \mathrm{H}\right.$, predicted $\left.\log L_{50}=-7.293\right)$ and meta $\left(X=3-S_{3} \mathrm{H}\right.$, predicted log $\mathrm{LD}_{50}=-4.659$ ) substituents, indicating that substituent at para position induces more pronounce of electron resonance effect on phenyl ring, causing electron attraction (charge flow) from $\mathrm{O} 7$ to $-\mathrm{SO}_{3} \mathrm{H}$ substituent. Consequently, the binding between $\mathrm{P} 8$ and $\mathrm{O} 7$ becomes looser and the phosphate group is easily bound to $\mathrm{O}-$ serine of the enzyme, resulting in higher insecticide activity of the corresponding compound.

\section{CONCLUSION}

We have used a semi-empirical molecular orbital calculation AM-1 to study the correlation between structure and the activity of a series of organophosphate insecticides against housefly (Musca nebulo L.). The best overall correlation is given by the computed molecular properties of atomic net charges of carbon-1, carbon-7 as well as Oxygen-7 as an active center of the insecticides. It is gratifying to observe that the hypothetical active center of the insecticides corroborate nicely in terms of possible mode of irreversible binding of the insectides to cholinesterase. The best QSAR model has been able to be used to design in silico new compounds of insecticide of organophosphate derivatives with better activity as compared to the existing synthesized organophosphate derivatives. From the molecular design, it has been found that 4-(diethoxy phosphoryloxy) benzene sulfonic acid is a good candidate as a new, more potent insectide of this series with log $L D_{50}$ prediction of -7.29 . The new designed insecticide compound is suggested to be synthesized and tested for its activity in laboratory for further verification. It has also been demonstrated from this result that semi-empirical AM1 method, although induces possible error sources, still seem to be a necessary and acceptable compromise for quantum pharmacological calculations on series of insecticide molecules of this size, including the search for active drug center.

\section{REFERENCES}

1. Zhu, K.Y., and Gao, J-R., 1999, Pestic. Sci., 55, 1, 11-17.

2. Durham, H.D., and Ecobichon, D.J., 1986, Toxicology, 41, 3, 319-332.

3. Ecobichon, D.J., Davies, J.E., Doull, J., Ehrich, M., Joy, R., McMillan, D., MacPhail, R., Reiter, L.W., Slikker, W., and Tilson, H., "Neurotoxic effects of pesticides", in The Effects of Pesticides on Human Health Vol. 18, Eds. Baker, S.R., and Wilkinson, C.F., Princeton Scientific, Princeton, NJ, 1990, 131-199.

4. Brown, A.E., 2005, Pestic. Inf. Leafl., 43, 1-13. 
5. Fukuto, T.R., 1990, Environ. Health Perspect., 87, 245-254.

6. Shi, L.M., Fan, Y., Myers, T.G., O'Connor, P.M., Paull, K.D., Friend, S.H., and Weinstein, J.N., 1998, J. Chem. Inf. Comput. Sci., 38, 2, 189-199.

7. Oloff, S., Mailman, R.B., and. Trospha, A., 2005, J. Med. Chem., 48, 23, 7322-7332.

8. Meneses-Marcel, Y., Marrero-Ponce, Y., MachadoTugores, A., Monterro-Torres, D.M., Pereira, J.A., Escario, J.J., Nogel-Ruiz, C., Ochao, V.J., Aran, A.R., Martinez-Fernadez, R.N., and Garcia, S., 2005, Bioorg. Med. Chem. Lett., 15, 17, 3838-3843.

9. Santana, L., Uriarte, H., González-Díaz, H., Zagotto, R., Soto-Otero, E. and Méndez-Alvarez, J., 2006, J. Med. Chem. 49, 3, 1149-1156.

10. Kamoshita, K., Ohno, I., Fujita, T., Nishioka, K., and Nakajima, M., 1979, Pestic. Biochem. Physiol., 11, 1-3, 83-103.
11. Naik, P.K., Sindhura, Singh, T., and Singh, H., 2009, SAR QSAR Environ. Res., 20, 5-6, 551-566.

12. Deswal, S., and Roy, N., 2006, J. Med. Chem. 41, 11, 1339-1346.

13. Hansch, C., Kurup, A., Garg, R., and Gao, H., 2001, Chem. Rev., 101, 3, 619-672.

14. Gandhe, B.R., Purnanand, Prasad, R. Danikhel, R.K., Shinde, S.K., Srivastava, R.K., Batra, B.S., and Rao, K.M., 1990, Pestic. Sci., 29, 4, 379-385.

15. Law, K.S., Acey, R.A., Smith, C.R., Benton, D.A., Soroushian, S., Eckenrod, B., Stedman, R., Kantardjieff K.A., and Nakayama, K., 2007, Biochem. Biophys. Res. Commun., 355, 2, 371378.

16. Hassall, K.A., 1990, The Biochemistry and Uses of Pesticide, Macmillan Press Ltd., Hongkong. 